\title{
SUSTAINABLE DEVELOPMENT IN EUROPEAN LAW - WITH THE SPECIAL REFERENCE TO THE CONTRIBUTION OF THE COLLABORATIVE ECONOMY
}

\author{
Simona Rudohradská, LLM, PhD candidate \\ Pavol Jozef Šafárik University in Košice, Faculty of Law \\ Departmen of Commercial Law and Business Law, \\ Kováčska 26, 04075 Košice \\ rudohradskasimona@gmail.com
}

\begin{abstract}
Today, with the current state of our planet, we face the challenges to which old solutions will no longer be applicable. At the initiative of the United Nations with cooperation of the European Union, the Agenda 2030 for Sustainable Development was created. Although the idea of resource efficiency is known from previous periods, Agenda 2030 is characterized by its versatility. Regardless of differences in capacities and other circumstances, respecting the other singularities, the Agenda 2030 is suitable for the development of all countries at all levels of development. Achieving economic prosperity in the private sector with the support of the public sector, creating social innovation, on condition to adhere environmental rules, is the ideal solution for the future. Can we call such a model the business of the future?
\end{abstract}

Keywords: sustainable development, Agenda 2030, priorities of European Commission, economic dimension, collaborative platforms

\section{INTRODUCTION}

The author deals in the submitted paper with the area of sustrainable development in a broad sense. Agenda 2030 for the sustainable development is a set of global commitments by which the international community responds to today's most serious challenges. The main subject of this contribution is to analyze Resolution adopted by the General Assembly received on 25 September 2015 and Communication from the Commission to the European Parliament, the Council, the European Economic and Social Commitee and the Commitee of the RegionsNext steps for a sustainable European future - European action for sustainability 
$\operatorname{COM}(2016) 739$ final, which contains a list of initiatives at the global level in relation to priorities of the European Commission created for the term of office 2019-2024. Mentioned initiatives to some extent quite understandably coincide with the priorities set by the European Commission. In the next part of this contribution we will try for deeper insight into the economic sphere and individual aspects in the context of Agenda 2030. Whereas the economic sphere of the Agenda 2030 itself is a relatively broad area, we will focus only on selected aspects, especially for the use of interconnection of individual key spheres of Agenda 2030 also in the field of business. At the same time we will try to point out on currently functioning models in the field of business which at first glance may not indicate completely clearly that by their presence on the market they meet the requirements established for business sustainability models. In this regard, we will point to a functioning model of a collaborative platform as part of a collaborative economy and we will briefly characterize the way in which the operation of the platform can adapt to the idea of three mutually balancing spheres of a sustainable development, which is a prerequisite for a sustainable economy.

\section{SUSTAINABLE DEVELOPMENT IN EUROPEAN LAW AND OTHER DOCUMENTS OF THE EUROPEAN UNION}

We meet with the notiton "sustainable development" in a primary law of the European union, exactly in Treaty on European union, Article 3 (5), where stands that: "In its relations with the wider world, the Union shall uphold and promote its values and interests and contribute to the protection of its citizens. It shall contribute to peace, security, the sustainable development of the Earth, solidarity and mutual respect among peoples, free and fair trade, eradication of poverty and the protection of human rights, in particular the rights of the child, as well as to the strict observance and the development of international law, including respect for the principles of the United Nations Charter. “1

In accordance with this wording, the role of European union is to contribut to the sustainable development of the Earth. With the respect to this task, 2015 was significant year. On September 25th, 2015 at the session of 70th General Assembly of United Nations, a new global framework for sustainable development has been adopted. ${ }^{2}$ Taking into account the objectives of this program, representatives as Head of State and Government and High Representatives took a huge step

Treaty on European union

Resolution adopted by the General Assembly on 25 September 2015, A/RES/70/1 available at: [https://www.un.org/en/development/desa/population/migration/generalassembly/docs/globalcompact/A_RES_70_1_E.pdf], accessed 09. March, 2020 
forward. Moreover, previsious legal framework was criticize and denoted as insufficient, cautious, incremental and incomplete. ${ }^{3}$ Agenda 2030, as progressive conception of United Nation, contains 17 goals and 169 related targets.

Accordingly to European law, it is necessary to emphasize that there is also Article 21 (3) of Treaty on European union. It's wording is as follows: "The Union shall respect the principles and pursue the objectives set out in paragraphs 1 and 2 in the development and implementation of the different areas of the Union's external action covered by this Title and by Part Five of the Treaty on the Functioning of the European Union, and of the external aspects of its other policies."

In this context, as it is stated in Article 21(1) subparagraph 2 "The Union shall seek to develop relations and build partnerships with third countries, and international, regional or global organisations which share the principles referred to in the first subparagraph. It shall promote multilateral solutions to common problems, in particular in the framework of the United Nations."

Undoubtedly, substance of the notion sustainable development is an important element on our way to meeting our commitments. It is essential to define why sustainability is so relevant and necessary. Unless we take the necessary initiatives at global level to sustain development, ultimately, such an approach would catch up with us. We face the challanges as youth unemployment, aging population, significant climate change, environmental pollution, exhaustible resource issues and migration. European union has a high level of economic development and commitment achieve "permanent" sustainable development firmly anchored in European Treaties. ${ }^{4}$

Following the context of European law, we also have the Regulation (EU) 2017/1601 of the European parliament and of the Council of 26 September 2017 establishing the European Fund for Sustainable Development (EFSD), the EFSD Guarantee and the EFSD Guarantee Fund (hereinafter referred to as: "Regulation 2017/1601"). Regulation 2017/1601 governs European fund for sustainable development, purpose of this Fund, structure, strategic board of the Fund and other meaningful questions connected with this Fund.

3 Walliser G.B.; Shrivastava P., Beyond Compliance: Sustainable Development, Business, and Proactive Law, Georgetown Journal of International Law, 2014-2015, vol. 46, p. 417, available at: [https://heinonline.org/HOL/LandingPage?handle=hein.journals/geojintl46\&div=19\&id=\&page=], accessed 09 . March, 2020

4 Next steps for a sustainable European future, European action for sustainability, $\{\operatorname{SWD}(2016) 390$ final\}, European Commission COM (2016) 739 final 
Agenda 2030 will for European union include "two work streams. The first work stream, presented in this Communication, is to fully integrate the SDGs ${ }^{5}$ in the European policy framework and current Commission priorities, assessing where we stand and identifying the most relevant sustainability concerns. A second track will launch reflection work on further developing our longer term vision and the focus of sectoral policies after 2020, preparing for the long term implementation of the SDGs. The new Multiannual Financial Framework beyond 2020 will also reorient the EU budget's contributions towards the achievement of the EU's longterm objectives."

\section{EUROPEAN COMMISSION PRIORITIES FROM A SUSTAINABLE DEVELOPMENT PERSPECTIVE}

Composition of the European Commission for the period 2019-2024 has set six essential priorities. Mentioned priorities are clearly linked to several 17 goals of the Agenda 2030. For the purposes of comparing and analyzing each goal, we shall use in particular, Resolution adopted by the General Assembly on 25 September 2015 (United Nations) (hereinafter referred to as "Resolution") and Communication from the Commission - European action for sustainability (hereinafter referred to as "Communication"). In that connection, it is necessary to add that the main 17 goals which are contained in the Resolution, are listed in wording of the Communication with the special atention to conditions of European union.

First priority is the European Green Deal. European union strives to be the first climate-neutral continent. Placing the environment in the first place speaks for itself. "Climate change and environmental degradation are an existential threat to Europe and the world. To overcome these challenges, Europe needs a new growth strategy that transforms the Union into a modern, resource-efficient and competitive economy where there are no net emissions of greenhouse gases by 2050 , economic growth is decoupled from resource use, no person and no place is left

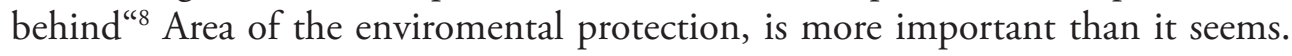
As it was mentioned, without properly working enviroment, hard work in other areas makes no sense. Undoubtedly, all industries have great importance for the economic side of our countries. Factories and industrial lines employ the citizens of our countries and create values that make our lives much more comfortable.

Sustainable Development Goals

Ibid.

Next steps for a sustainable European future, op. cit., note 4

European Commission, Strategy, A European Green Deal, available at: [https:/ec.europa.eu/info/ strategy/priorities-2019-2024/european-green-deal_en], accessed 09. March, 2020 
Through greater availability of vehicles and greater use of trucking for transport (instead of the previously preferred trains) are goods more accessible to us. However, we "pay a tax" in the form of polluted air. Measures which should be applied are summarized in document of European union called The European Green Deal. ${ }^{9}$ Implementation timetable of key actions is included in the Anex to the mention document. ${ }^{10}$ The creation of new measures in this case will not be sufficient, whereas at the same time the original ones need to be effectively adapted. ${ }^{11}$ Having regard to the foregoing we should state, the European Green Deal is a highly anticipated document.

The area of the enviroment goes across most goals outlined in the Resolution and (naturally) in the Communication. However, it is most related to the goal 2 - "End hunger, achieve food security and improved nutrition and promote sustainable agriculture"12, goal 3 "Ensure healthy lives and promote well-being for all at all ages", goal 6 - "Ensure availability and sustainable management of water and sanitation for all", goal 7- "Ensure access to affordable, reliable, sustainable and modern energy for all" and goal 13 - "Take urgent action to combat climate change and its impacts".

The second from the six priorities is An Economy that works for people. As it is stated "individuals and businesses in the EU can only thrive if the economy works for them. " ${ }^{13}$ In this context small and medium-sized enterprises are in the focus of attention. Areas of equal importance are connected with the completing the Capital Markets Union and deepening the Economic and Monetary Union. ${ }^{14}$ In this context, second priority (european economy) is the most connected with the goal 4 "Ensure inclusive and equitable quality education and promote lifelong learning opportunities for all". ${ }^{15} \mathrm{~A}$ natural precondition for a well-functioning economy is a sufficient amount of skilled manpower. It is natural, that countries with quality and progressive education system have more advanced economies. In this area, more than any other, it is necessary to incorporate the process of education and the creation of a suitable work base.

9 Communication from the Commission, the European Green Deal, Brussels, 11.12.2019,COM(2019) 640 final

10 Anex to the European Green Deal, Brussels, 11.12.2019 COM(2019) 640 final ANNEX

11 Communication from the Commission, the European Green Deal, op.cit., note 9 ,COM(2019) 640 final, p. 4

12 Next steps for a sustainable European future, op. cit., note 4

13 An economy that works for people, Working for social fairness and prosperity, available at: [https://ec.europa.eu/info/strategy/priorities-2019-2024/economy-works-people_en], accessed 09. March, 2020

14 An economy that works for people, ibid.

15 Next steps for a sustainable European future, op.cit., note. 4, p. 5 
A Europe fit for the digital age is the third from the list of European prorities. In the previous season there was Digital single market, as a one of ten priorities of European Commission. Member States of European union with the support of European Commission tried to provide better possible access to the online world for individuals and also for businesses. Digital single market, whose predecessor was the internal market, is connected with the free movement of persons, services and capital. In the digital area it will mainly be about free movement of services and capital. Understandably, it is hard to imagine the free online movement of persons in cyberspace. The third priority is related in particular with goal 9 "Build resilient infrastructure, promote inclusive and sustainable industrialization and foster innovation". Much discussed become new initiative in the area of collaborative platforms - Digital Services Act. This planned document will upgrade our liability and safety rules for digital platforms, services and products. ${ }^{16}$ Liability of digital platforms as part od collaborative economy has been the subject of many professional discussions and professional publications. Previous access to questions associated with liability of collaborative platforms consisted on a caseby-case approach.

Promoting out European way of life - is the title of the European Commission's fourth priority. Main idea of this priority is to protect european citizens and our core values. ${ }^{17}$ Despite of the modernization of our society and digitalisation, many Member States of the European union still struggle with high levels of corruption and their citizens' suffer from lack of confidence in the judiciary, the police, the public prosecutor's office or other public authorities. Transparency requirements are increasing, affordable justice for everyone based on the principle of equality before the law must be a matter of course for every developed country. This iniciative is most connected with the goal 16 - "Promote peaceful and inclusive societies for sustainable development, provide access to justice for all and build effective, accountable and inclusive institutions at all levels".

The fifth priroity is A stronger Europe in the world - with emphasis on reinforcing our responsible global leadership. ${ }^{18}$ As it is stated in the offficial webside of the European Commission : "A strong, open and fair trade agenda, making Europe an attractive place for business, is key to strengthening the EU's role as a global

16 A Union that strives for more, My agenda for Europe, By candidate for President of the European Commission Ursula von der Leyen, Political Guidlines for the next European Commission 20192024, p. 13

17 Promoting our European way of life, avalaible at: [https://ec.europa.eu/info/strategy/priorities-2019-2024/promoting-our-european-way-life_en], accessed 26. March 2020

18 A stronger Europe in the world, available at: [https://ec.europa.eu/info/strategy/priorities-2019-2024/ stronger-europe-world_en], accessed at: 26. March 2020 
leader while ensuring the highest standards of climate, environmental and labour protection. European leadership also means working shoulder-to-shoulder with neighbouring countries and partners, introducing a comprehensive strategy on Africa and reaffirming the European perspective of the countries of the Western Balkans". From this wording is clear that European union is fully aware that for maintaining of its position, it is necessary to constantly deepen the current successes and addapt priorities to current need of the population with the regard development. In that context, we dare to insist thath all of the goals of the Agenda 2030 are connected with strengthening the position of the European union in the world.

A new push for European democracy - is the last priority od European Commission. Last European election took place in 2019. High turnout legitimized the interest of European Union citizens to participate on issues related to the work of the European Union. Conference on the Future of Europe, which should be launched on Europe day, 9th May 2020 will run for two years. ${ }^{19}$ This conference will provide space to give Europeans a greater say on what the European Union does and how it works for them. ${ }^{20}$ From the perspective of the Agenda 2030, is European democracy associated with the goal 16 - "Promote peaceful and inclusive societies for sustainable development, provide access to justice for all and build effective, accountable and inclusive institutions at all levels". ${ }^{21}$ For sustaining european democracy and its development is equally important goal 10 "Reduce inequality within and among countries" ${ }^{22}$ It is not in vain that the community is only as strong as its weakest link. This partial goal is hidding more than just the need for equality. The whole idea of Agenda 2030 is built on cooperation of involved individual entities regardless of the state of development. From reducing the disparities between Member States thus will not benefit only the citizens of the European Union for achieving their own goals but also for those, which are contained in the Agenda 2030.

\section{SUSTAINABILITY AS CRUCIAL FACTOR}

It is natural, that modern states urge for rapid development. With increasing digitalization we reach the results faster, than we once imagined. Dynamic shift in the field of technologies forces us to adapt to this fast time. Of course that it brings

\footnotetext{
19 Shaping the Conference of the future of Europe, Press release, available at: [https://ec.europa.eu/ commission/presscorner/detail/en/ip_20_89], accessed 26. March 2020

20 Ibid.

21 Next steps for a sustainable European future, op.cit., note 4, p. 7

22 Next steps for a sustainable European future, op.cit., note 4, p. 5
} 
many benefits, especially when it comes to healthcare and treatment, but also other conveniences that make our life more comfortable. But we can not forget, that there is one area that suffers from rapid development. The environment is rightly getting into the deeper awareness of both, the professional and lay public. Sustainability is now a feature, that must be part of the development and it is an integral part of all three dimensions: economic, social and enviromental.

If we should characterize sustainability as a property, we would need to break down this notion in the context of long-term. The key aspect, from the long-term perspective, is the responsibility (or liability). Responsibility as a regular element, is mainly encountered in the law of obligations, but for example also in a corporate law or in many other branches of law. However in the context of sustainability, responsibility has a much broader scope than in standard legal notion. In the standard application of the law (for example in claiming damages), we have clearly established who is obliged and who is entitled, having regard to the circumstances. Now we are responsible for the coming generations and to some extent, we also shape the way of life for future generations. Having regard to the foregoing, when we are speaking about sustainability, when should keep on mind particularly responsibility.

\section{ECONOMIC DIMENSION AS A PART OF AGENDA 2030}

Main idea of the Agenda 2030, as follows from the title of this post, is balance of the three key dimensions: economic, social and enviromental dimension. It would be difficult to determine which sphere of three mentioned, is the most imporant for proper functioning of our society in terms of sustainability. All spheres are interconnected and more or less depend on each other. In relation to the economic sphere, it is appropriate to state what specifically this term includes. From the point of view of the activities of the European Union, this will be in particular: "responsible trade and investment policy as an instrument of SDG implementation contributing to boosting jobs, sustainable growth and investment in Europe and outside. ${ }^{\text {23 }}$ this is discussed in a other document of European union, Strategy "Trade for all" ${ }^{42}$, which was adopted following the adoption of the United Nations Agenda 2030. Naturally, several entities, not only the European Union, are involved in the functioning of economic dimension. It will be primarily the Member States, entrepreneurs offering their goods or services on the market and consumers. States can make a significant contribution to the business sector with a regard to economic dimension implementing appropriate measures and adopt-

\footnotetext{
23 Next steps for a sustainable European future, op.cit., note 4, p. 7

24 Trade for All, COM (2015) 497 final
} 
ing appropriate legislation. Under favorable conditions and in a business-friendly environment entrepreneurs will be more motivated by their part to contribute to creating a sustainable economy. Consumer participation is equally important. Although it does not seem, they form an equally important part of the imaginary triangle of the economic sector.

In context of economic dimensions is often mentioned The Triple Layered Business Model Canvas. Apposite definition is the one by Joyce and Paquin, who characterize it as "a tool for exploring sustainability-oriented business model innovation. It extends the original business model canvas by adding two layers: an environmental layer based on a lifecycle perspective and a social layer based on a stakeholder perspective. " 25 There is no coincidence that this tool connects three layers exactly like the Agenda 2030, although the fact that it primarily concerns business models. Economic layer (based on the original BMC), Environmental life cycle layer and Social stakeholder layer. ${ }^{26}$ As an suitable example, we can mention the company dealing with distribution of coffee and other related equipments, Nespresso.

In our opinion, important element playing the role in process concerning sustainability in business is also motivation of entrepreneurs to contribute willingly in order to achieve a higher public interest. It is a logical fact that business entities are mainly motivated by their own economic interests than they should prefer demands resulting from sustainability. Another question arising from this issues is, which entity should represent motivating element.

\section{COLLABORATIVE ECONOMY AND ITS CONTRIBUTION TO THE SUSTAINABLE DEVELOPMENT}

Following the aspects of economic dimension of Agenda 2030, as we mentioned above, there are a lot of possibilities how to use resources efficiently. As most effective way to get to status of sustainable development in our economy, is to use systematic balancing of profit efforts on the one hand, and on the other hand aspiration to get higher interest at the same time to support the environmental sector. When we speak about increase of efficiency we should definitely not forget that we already have functional models that are capable of saving our resources in a broader sense. Of course, we do not mean anything other than the collabora-

25 Joyce A.; Paquin, R. L., The triple layered business model canvas: A tool to design more sustainable business models, Journal of Cleaner Production, vol. 135, 1 November 2016, pp. 1474-1486

26 Joyce, A.; Paquin, R.; Pigneur, Y., The triple layered business model canvas: a tool to design more sustainable business models, ARTEM Organizational Creativity International Conference, 26-27 March 2015, Nancy, France 
tive economy in particular, its probably the most important part, collaborative platforms. In the area of collaborative economy, is within the discussions of the professional public, addressed many issues in terms of various aspects of collaborative platforms. The market position of collaborative platforms has been addressed relatively intensively, as well as the liability regime of collaborative platforms. In this context, we would like to draw your attention to the publications by Laura Rózenfeldová and Regina Hučková in article Collaborative Economy in Transport (certain issues) ${ }^{27}$ and also in article Collaborative Economy - open problems and discussion (with regard to commercial and tax issues) by Regina Hučková, František Bonk and Laura Rózenfeldová. ${ }^{28}$ Equally crucial are issues related to platform taxation whether the position of collaborative platforms from the point of view of competition law. It is also necessary not to forget the aspects of personal data, which are collectivized and processed by collaborative platforms or a new category of non-personal data also referred to as other than personal data.

The issue of the collaborative economy has so far only been comprehensively summarized at European Union level uniformly in a other document of European union - An European agenda for the collaborative economy. This document have brought framework definition of collaborative economy, which we can characterize as "business models where activities are facilitated by collaborative platforms that create an open marketplace for the temporary usage of goods or services often provided by private individuals. The collaborative economy involves three categories of actors: 1. service providers who share assets, resources, time and/or skills - these can be private individuals offering services on an occasional basis ('peers') or service providers acting in their professional capacity ("professional services providers"); 2 . users of these; and 3. intermediaries that connect — via an online platform - providers with users and that facilitate transactions between them ('collaborative platforms'). Collaborative economy transactions generally do not involve a change of ownership and can be carried out for profit or notfor-profit. "29 One of the last legislative act following the online intermediaries is Regulation (EU) 2019/1150 of the European Parliament and of the Council of 20 June 2019 on promoting fairness and transparency for business users of online intermediation services. Significant expected legal act which the European

27 Rózenfeldová. L.; Hučková. R., Collaborative Economy in Transport (certain issues), STUDIA IURIDICA Cassoviensia, year 7, no. 1, 2019, available on: [https://sic.pravo.upjs.sk/index.php/sk/21-casopis-72019-1], accessed 29. April 2020

28 Hučková, R.; Bonk, F.; Rózenfeldová, L., Collaborative Economy - open problems and discussion (with regard to commercial and tax issues), STUDIA IURIDICA Cassoviensia, year 6, no. 2, 2018, available on: [https://sic.pravo.upjs.sk/index.php/sk/20-casopis-62018-2], accessed 29. April 2020

29 A European agenda for the collaborative economy, $\{\operatorname{SWD}(2016) 184$ final $\}$, Brussels 2.6.2016, $\operatorname{COM}(2016) 356$ final, p. 3 
Union plans to create is the Digital Services Act. Taking into account that Directive 2000/31/EC of the European Parliament and of the Council of 8 June 2000 on certain legal aspects of information society services, in particular electronic commerce, in the Internal Market as know as Directive on electronic commerce is in effect already twenty years, and whereas the technological means have shifted dramatically, technological innovation did not bypass area of business, creation of new business models and business resources have also changed significantly, and an overall change in the online business environment suggest, that the announced legislation in this area is desirable.

If we should give a concrete example of a collaborative platform that effectively contributes to saving depletable resources we would like to emphasize the BlablaCar platform. Apart from other issues related to the functioning of platforms in the light of sustainable development, this platform shall make an appropriate contribution. This platform was based on a really interesting story and idea with a social subtext. As stated on the official website ${ }^{30}$ of the platform, its founder Frédéric Mazzela wanted to get home on Christmas in 2003 and saw a lot of vehicles on the road, just with one person - driver. And so the idea came into being - to offer a financial reward, resp. replacement for gasoline for one free place in the car. In terms of the three aspects that are key to sustainable development - economic, enviroment and social dimension, we can state with exaggeration that the conduct of the said platform affects each of these three areas. From an economic point of view the platform saves the financial resources of its users, at the same time as an income of business entity contributes to the economy. From the perspective of the social dimension, of course in a broad sense, this platform connects people in a positive sense, for a positive purpose. Even with such small steps we can implement pro-social activities that are beneficial for both parties. From the enviromental point of view carpooling saves exhaustible resources that are necessary when traveling, ie fuel for cars, as well as the emissions generated by motor vehicles while driving.

By referring to this platform operating in the field of transport we wanted to draw attention to the fact that we already have many interesting ways on the market which fulfill the idea of sustainability. The concept of collaborative economy is in itself based on the idea of sharing, more precisely resource sharing. Therefore, given the importance of the collaborative economy in the context of the overall economy, the European Union does not underestimate the potential of a collaborative economy and pays due attention to it.

30 BlaBlaCar, available at: [https://www.blablacar.co.uk/], accessed 29. April 2020 


\section{CONCLUSION}

Through the analysis of the documents we announced in the introduction of our paper we were able to prove that the goals appearing in the Agenda 2030 have also been significantly reflected in the priorities of the new Commission, which will operate in the 2019-2024 term of office. European union is attentive to the needs of its citizens, reflecting the global situation and development. In this context, it is desirable to use a formula that appropriately describes the efforts of the European Union thath "many hands make light work". Having regard to the provisions of the founding Treaties, many of the objectives contained in the 2030 Agenda can already be achieved more effectively at European Union level, jointly and with the participation of all Member States, for whom this effort will be beneficial. In addition from the perspective of the economic sphere of a sustainable economy, we currently have business models at our disposal, which can, through their functioning, contribute to the pursuit of a sustainable economy. In the last chapter of our paper, we tried to point out the advantages offered by collaborative platforms which not only seem to contribute to sustainability as such. In our opinion, in the context of submitted contribution, it is important not to forget to mention the area of collaborative economy. One of the reasons is the very idea of a collaborative economy-resource sharing. Reffering the concrete working model of the digital platform we have highlighted some of the benefits which collaborative platforms bring to all key spheres of sustainable development. These business models are capable of saving our resources at the economic level, developing the social sphere in an appropriate way, and helping the environmental area through their activities. The European Union certainly does not underestimate the potential of collaborative economy. Through its initiatives, the European union seeks to create suitable, fair and safe conditions for the operation of modern technologies also in the business environment. In relation to the planned activities in the near future, we can mention preliminary discussions on creating a comprehensive legal framework for the regulation of online services, so- called Digital services act. 


\section{REFERENCES}

\section{BOOKS AND ARTICLES}

1. A Union that strives for more, My agenda for Europe, By candidate for President of the European Commission Ursula von der Leyen, Political Guidlines for the next European Commission 2019-2024

2. Joyce, A.; Paquin, R.; Pigneur, Y., The triple layered business model canvas: a tool to design more sustainable business models, ARTEM Organizational Creativity International Conference, 2627 March 2015, Nancy, France

3. Joyce A.; Paquin, R.L., The triple layered business model canvas: A tool to design more sustainable business models, Journal of Cleaner Production, vol. 135, no. 1, November 2016, pp. $1474-1486$

\section{EU LAW}

1. A European agenda for the collaborative economy, $\{\operatorname{SWD}(2016) 184$ final $\}$, Brussels 2.6.2016, $\operatorname{COM}(2016) 356$ final

2. Communication from the Commission, the European Green Deal, Brussels, 11.12.2019, $\operatorname{COM}(2019) 640$ final

3. Next steps for a sustainable European future, European action for sustainability, \{SWD(2016) 390 final\}, European Commission COM (2016) 739 final

4. Trade for All, COM (2015) 497 final

5. Treaty on European union (Consolidated version)

6. Treaty on the Functioning of the European union (Consolidated version)

7. Anex to the European Green Deal, Brussels, 11.12.2019 COM(2019) 640 final ANNEX

\section{WEBSITE REFERENCES}

1. A stronger Europe in the world, available at: fhttps://ec.europa.eu/info/strategy/priorities-2019-2024/stronger-europe-world_en], accessed 26. March 2020

2. An economy that works for people, Working for fairness and prosperity, available at: [https:// ec.europa.eu/info/strategy/priorities-2019-2024/economy-works-people_en], accessed 20. June 2020

3. BlaBlaCar, available at: [https://www.blablacar.co.uk/], accessed 29. April 2020

4. European Commission, Strategy, A European Green Deal, available at: [https://ec.europa. eu/info/strategy/priorities-2019-2024/european-green-deal_eng], accessed 20. June 2020

5. Hučková, R.; Bonk, F.; Rózenfeldová, L., Collaborative Economy - open problems and discussion (with regard to commercial and tax issues), STUDIA IURIDICA Cassoviensia, year 6, no. 2, 2018, available on: [https://sic.pravo.upjs.sk/index.php/sk/20-casopis-62018-2], accessed on 29. April 2020

6. Promoting our European way of life, avalaible at: [https://ec.europa.eu/info/strategy/priorities-2019-2024/promoting-our-european-way-life_en], accessed at 26. March 2020 
7. Resolution adopted by the General Assembly on 25 September 2015,A/RES/70/1 available at: [https://www.un.org/en/development/desa/population/migration/generalassembly/ docs/globalcompact/A_RES_70_1_E.pdf], accessed 09. March, 2020

8. Rózenfeldová. L.; Hučková. R., Collaborative Economy in Transport (certain issues), STUDIA IURIDICA Cassoviensia, year 7, no. 1, 2019, available at: [https://sic.pravo.upjs.sk/index. php/sk/21-casopis-72019-1], accessed 29. March 2020

9. Shaping the Conference of the future of Europe, Press release, available at: [https://ec.europa. eu/commission/presscorner/detail/en/ip_20_89], accessed 26. March 2020

10. Walliser, G.B.; Shrivastava P., Beyond Compliance: Sustainable Development, Business, and Proactive Law, Georgetown Journal of International Law, vol. $462014-$ 2015, available at:[https://heinonline.org/HOL/LandingPage?handle=hein.journals/ geojintl46\&div=19\&id=\&page=], accessed 20. June 2020 